\title{
SOFA AS THE EXPRESSION OF ELEGANCE IN TRADITIONAL KAYSERI HOUSES \\ Vacit İMAMOĞLU
}

Received: 03.03 .2010

Keyword: sofa; Ottoman interiors; traditional decoration; Kayseri dwellings; mihrap walls.
The town of Kayseri is in the geometric center of Anatolia and on the ancient trade routes connecting the west with the Middle East and Asia. Although its history may be traced back to earlier periods, during the first millennium BC, Kayseri was named as Mazaca. Later, after the establishment of the Roman province in $17 \mathrm{AD}$, it was called Caesare and with the later Arabic rule, Kaysariye. Byzantines constructed the present citadel and outer city walls. Later on, during the Seljuk period, Kayseri became one of the most important centers in Anatolia with many religious and secular public buildings. The flourishing city spread beyond the citadel and a number of town quarters were established around the city walls. In the late 16th century, under the Ottoman rule with a population of 40,000, Kayseri was the largest city of Anatolia after Bursa, four-fifths of its population being Muslim and the remaining, Christian. Evliya Çelebi visited Kayseri around 1650 and described it as a lively urban setting comparable to Bursa and Edirne (Evliya Çelebi Seyahatnamesi, 1970, 68). The town had a major earthquake in 1835 destroying many of its buildings and killing more than 660 people (Ainsworth, 1842; Ahmet Nazif, 1987).

The economic boom after the Second World War gradually forced Kayseri to turn into a so-called "modern" town with medium-height, densely built apartment buildings at the expense of destroying the historical quarters. In the last fifty years, drastic changes have taken place and a rich corpus of traditional urban houses has disappeared. Today one can still see a very small proportion of traditional neighborhoods and the last examples of houses mostly in quite poor condition.

\section{TRADITIONAL HOUSES IN KAYSERİ}

A traditional Kayseri house, in general, is the outcome of a natural and unpretentious building process, inward looking and asymmetrically growing around a courtyard or a small garden. The fact that this historical house form is quite common in many Anatolian, Middle Eastern and 
Figure 1. Ground floor plan of Gavremoğlu House, construction date: 1774

Figure 2. South elevation of the sofa in the harem section of Güpgüpoğulları Konak, in 1987. Construction date: 1419-1497.
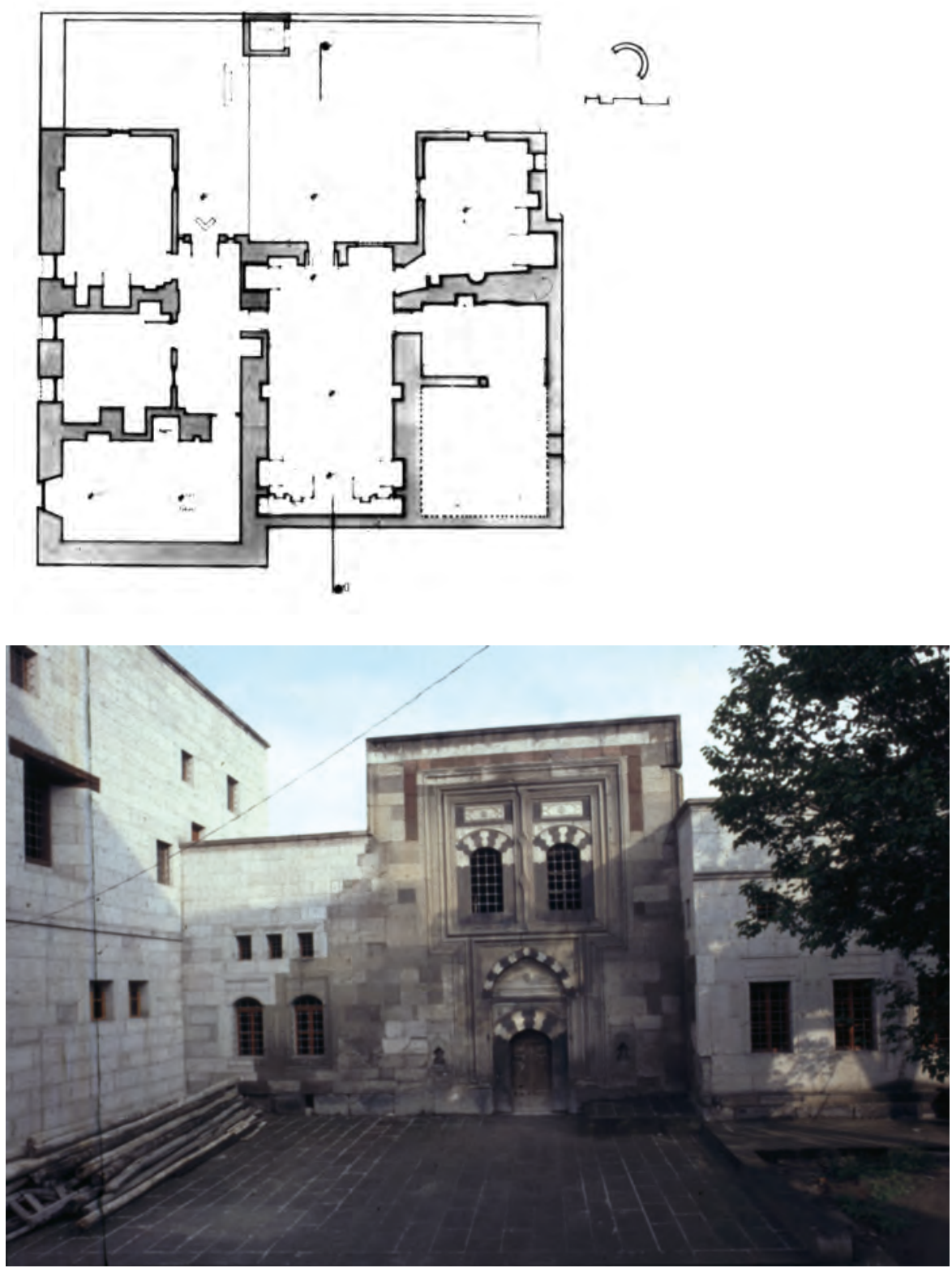

Mediterranean cities, with endless design variations, shows a good correspondence between the form and style of living (Figure 1).

Houses were generally single-storey with basements. They were composed of simple rectangular prisms; having flat roofs, plain elevations with little decorations, sharp corners and few windows. All were built of stone and timber, which helped to produce purity, uniformity and power in the spaces and the overall design. The openings and the general character of the main structures bear features of the Seljuk and southeastern Anatolian styles. Elevations facing courtyards resemble those in Diyarbakır, Urfa and Mardin, where one can detect the effects of Assyrian, Persian, Afghan and Egyptian architecture (İmamoğlu, 2006, 1980)(Figure 2).

In general, a simple plan dominated Muslim houses for at least four hundred years: a main hall or sofa was the nucleus for the enclosed portion of a house. It served as a major space as well as a distribution hall to 
other rooms; on one of its sides was the harem (bedroom and family living room) and on the other, tokana (kitchen and winter living space). With the increasing demands of the family for another room, a new room was added relatively easily to one of the wings of the house. Basements were allocated to services and storage; a stable connected to a barn was the most common function at this level. Many of the family activities were carried out in courtyards. Rooms were oriented towards courtyards and service spaces were directly connected to them. The contrast between exterior and interior of houses is also noteworthy. Simple, powerful, monochromatic and somewhat "masculine" exterior expressions are in clear contrast with the complexity, delicacy, colourfulness and "femininity" of the interiors; they are like secret paradises for families and individuals.

There was almost no or minute differences between Muslim and Christian houses in Kayseri until the Tanzimat period, after which Christians became prosperous and started building large residences under the influence of Western architecture. These new buildings mostly had a symmetrical and geometrical plan; generally a self-contained, complete rectangle such that any additions or subtractions of space would ruin the general layout. There were no differentiation between rooms, neither a concern about gender segregation. Additionally they had more windows, having an extraverted character. Hence, some differences between the houses of two groups of population became obvious (İmamoğlu, 2001). Since the sofa is a traditional type of space in Kayseri houses and the majority of such buildings belonged to Muslim population, the present paper will deal with the prevailing house types and the sofas in the last three to four centuries in the town.

\section{SOFA IN THE TRADITIONAL KAYSERİ HOUSE}

The sofa is the main and the most impressive space in Kayseri houses. To use Alexander's (2002, Book III, 416) term, it is the "unforgettable" space with respect to its size, position, volume, character and structure. It is large, measuring 700-800 $\mathrm{cm}$ in length, $400-500 \mathrm{~cm}$ in width and 500-700 $\mathrm{cm}$ height; a lofty interior. It is located just in the center of the house as a simple, clear rectangular prism. While the volumes of harem room, tokana and other rooms stay on a smaller domestic scale, sofa sticks out from the rest of the building mass by its larger volume and extra height. Hence it can easily be detected from outside by its size and embellishments on its entrance façade (Figure 2).

The attention paid to interior decoration of the sofa is also special and elaborate. With its fine wood paneling and details, meticulous painting on wall panels and ceilings, selection of the best carpets, kilims and carpeted pillows for furnishings, this room appears as the showpiece of the house. Although most of the traditional sofas were demolished, one may easily see a colourful variety of design approaches from photographs and drawings of the recorded examples (İmamoğlu, 2006; Çakıroğlu, 1952).

The sofa, besides its role as a distribution space, was used for a number of purposes: as a reception hall, a guest room, a living room, a prayer hall, and for the older members of the family, a sleeping room. Because of its large volume and position in the house, it was the dominant space within the house and people using this space had an eye on other people coming in and going out. The sofa resembles the salon (the living roomguest room) of contemporary urban dwellings in Turkey and particularly 
Figure 3. Interior elevation of the entrance wall of Gavremoğlu House.
1. Fourteen sofas that were closely examined or known by the author in

Kayseri were: Güpgüpoğulları, Gavremoğlu, Zennecioğulları, Mollaoğulları, Cıngıllıoğlu, Sipahioğlu, Camızlar, Öztaşçı, Baldöktü, Bağdatlı, Gömlekçioğlu, Aslandağ, a house in Çifteönü and one in Hasinli neighborhood. Among these all entrance walls were oriented to north, only that of Mollaoğulları's was oriented to east and that of Öztaşçı's to southwest direction. A recent research project carried out in Gesi and eight villages nearby, located in $17-30 \mathrm{~km}$ east and northeast of Kayseri supported this finding. Doors of sofas in most of the traditional houses in this region were also oriented to north (İmamoğlu, 2010).

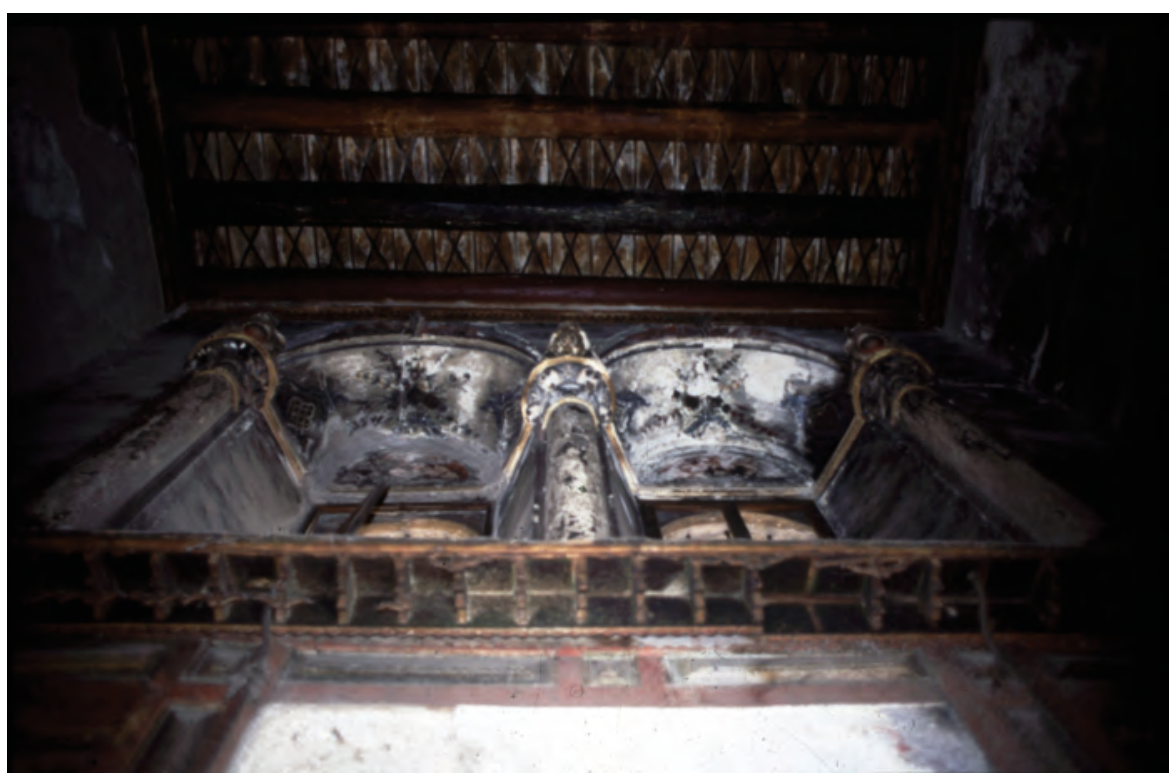

in Kayseri today. Although every flat or house has a salon, the majority of families do not use it regularly. Instead they use a smaller family living room, named as "sitting room" for daily living and reserve the salon for guests and important occasions like religious holidays, weddings or similar ceremonies, social gatherings and funeral meetings (İmamoğlu, 1988). In traditional houses too, the sofa was the public face of the house and seems to continue this function today by changing its name and character in adapting to contemporary living. The family in old days, as today, spent their daily life in a less extravagant harem room, more or less similar to the sitting room of our time. While harem room and other rooms were equipped with a gusülhane (built-in bath cubicle) due to its formal character, sofas lacked this provision.

The sofa is an introverted space in principle. However, it opens to the courtyard with a door and one or two flanking windows or openings on the top or the sides of this door. The proportion of window area to room area ranges between three to six percent only. Since this is a very small proportion, to have more natural light, sofa doors were generally kept open during the day. This is the only side of the sofa with openings to the outside (other walls never had any windows); the interior space was dimly lit and had a dramatic and mysterious character (Figure 3).

The openings of the sofa were consistently oriented towards north, in line with the orientation of the house. (Twelve out of 14 traditional Muslim houses examined or known by the present author have this orientation(1).) In the climate of Kayseri one would expect just the opposite: regardless of the sizes of walls or windows, any exposure to the south would help to warm up the space in daytime and store some heat for the night. Inquiries with the local old people and further considerations somewhat indicated that this might have originated mainly from the Islamic religion. During their daily prayers, Muslims orient themselves toward Mecca (i.e. South in Kayseri). Sofas were designed in such a way that, first of all, nobody would doubt which direction to turn for prayer which is approximately true south in Kayseri, which is the wall opposite the entrance. Secondly, no one should pass in front of the praying person during the prayer. This 
consideration was taken care of by a clear separation of the entrance area (sekialtı) and the main floor:

a. Circulation in the sofa was confined to the sekialts area (which is a small portion of the room next to the entrance door), people going to harem or tokana could directly pass from this part, without disturbing the praying person(s).

b. Main floor of the room was two or three steps higher than the entrance or sekialtı area, hence the main floor was clearly defined and not directly affected by circulation.

c. Main floor was made of timber and furnished with carpets and rugs, while sekialtı was paved with stone; someone going up to the main floor was expected to take off his/her shoes there; hence the main floor was always kept tight and clean.

One interesting point about sofas is the lack of any specific foci in the room other than the south wall itself. Neither a fireplace nor a şerbetlik (a decorated alcove for preparing and serving sherbet and beverages) -which were focal points in many of the traditional rooms in Anatolia- was utilized in classical Kayseri sofas. Instead, a series of wall panels, cupboard doors, shelves and other wall elements were used in a harmonious way and every design element was somewhat blended within a design theme.

Heating in traditional Kayseri houses was difficult. Although sofas were the most important spaces, they did not have a fireplace or any kind of built in heating devices. It is known that fireplaces were seldom used in the rooms of Muslim houses in Kayseri, and generally a hearth was located in tokanas, which were used as a kitchen and as a winter living room (İmamoğlu, 2006, 51-2). If a fireplace was used in a room, it became the center of that space. One expects that in a cold climate, like the one in Kayseri, the largest and the most prestigious room of the house oriented to the north was to be provided with a fireplace, at least in the houses of upper socio-economic-status families. But this was not the case and none of the sofas were constructed with a fireplace. This may have multiple reasons:

a. One explanation may be the ceremonial character of the sofa: It was used mostly for important and formal occasions, for shorter periods of time, and people could perhaps carry out such brief activities without a permanent heat source.

b. Since the room was large and the ceiling was relatively high, an effective heating would probably not be possible.

c. Another explanation may be that, sofa may be considered a kind of family shrine and the south wall of it may be considered the climax of the room design, and any other foci -like a fireplace- in the space would probably weaken the effects of this altar-like wall.

Of course there are examples of houses with rooms equipped with fireplaces in the town as well as in its nearby villages, generally built during the 19th century. However, sofas represent the deep-rooted architectural tradition and local culture in Kayseri and hence, did not change much. Instead, they were kept as they were in the past and were supplied generally with portable charcoal brazier(s) to warm up people at a very low level. Heating the whole space was not seriously attempted until 
Figure 4. A view from the sofa of a house in Çifteönü quarter, a 19th century building.

Figure 5. West wall of Gavremoğlu's sofa.

Figure 6. A view from the Bezircioğlu's sofa, renewed in 1947.
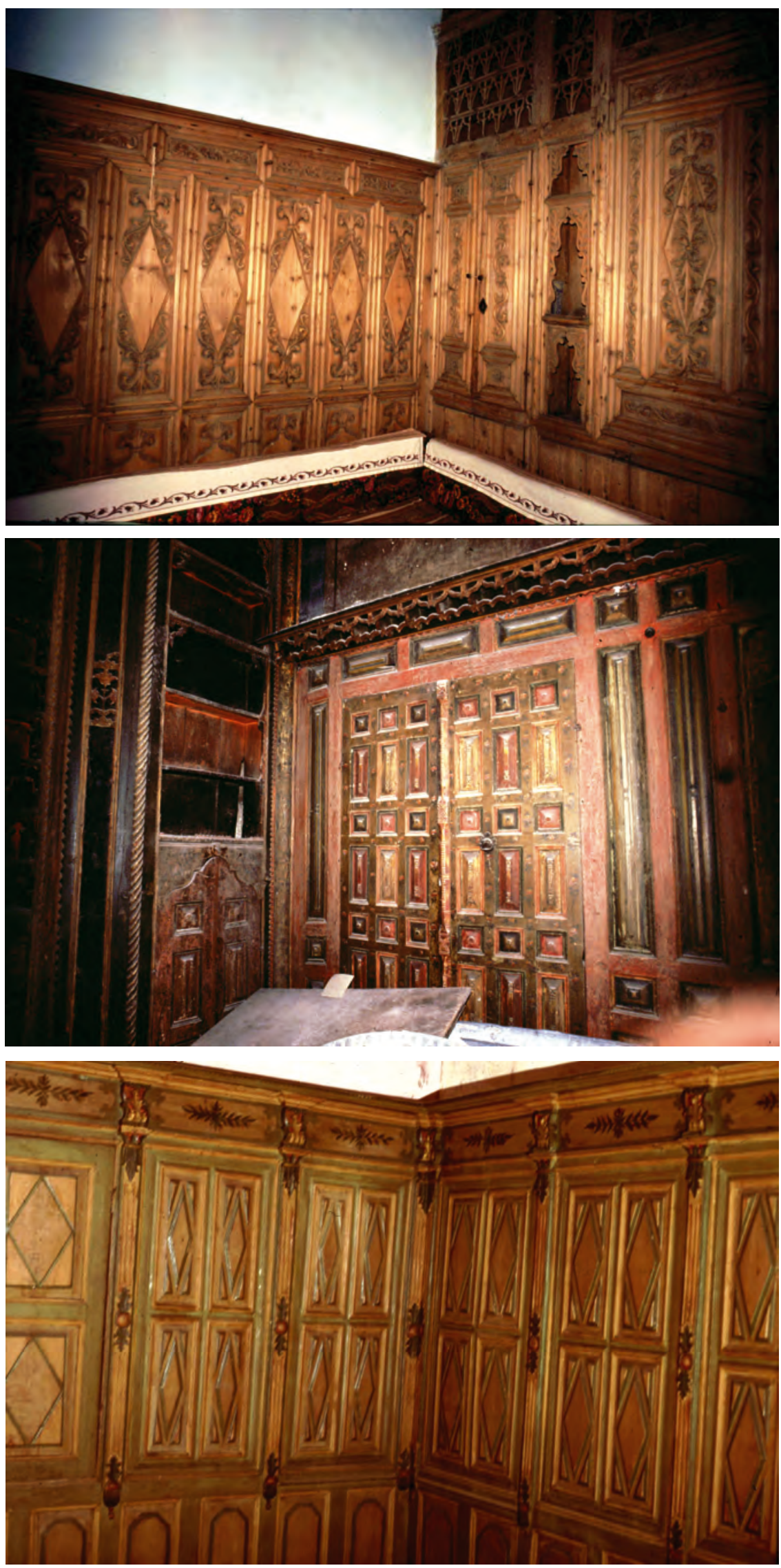
the widespread use of stoves in late 19th century, when various types of stoves were employed in houses.

\section{WALLS AND WALL ELEMENTS OF SOFA}

Design of sofas had a long tradition in Kayseri. Although it evolved slowly in the last 400 years, it did not change much. Among the four walls, the most and the least elaborated ones were opposite to each other and designed to be on the short sides of the space:

1. The entrance side was the plain one, including the entrance door and one or two flanking windows or openings on top. The door, with single or double swing, was a decorated element made of heavy timber and intricate tongue and groove connections that usually created a functional aesthetic. In some cases, doors were plain but extra carvings or moldings were applied on their exteriors. Inside surface of the entrance wall was either paneled with timber or left as plastered. Although this side was generally kept simple and plain, if any kind of decoration was applied, it was above the door level, under or around the windows. In Öztaşçı's sofa (1877), a band of frescoes with flower figures run above the entrance door, at the bottom and around the windows (İmamoğlu, 2006, Figure 76a, 76b). In addition to that, scenery of an imaginary palace complex was depicted on the surface next to the second window (İmamoğlu, 2002). In Gavremoğlu's sofa (1774) however, Baroque type decorations were concentrated around and between the windows (İmamoğlu, 2006, 205, Figure 3).

2. Long side walls of sofas were mainly divided into two sections (or zones) from a level of $250-270 \mathrm{~cm}$. height. The first level was designed with the sitting platform (sedir) at the bottom and a continuous, unifying shelf at the top. This surface here was totally covered with decorated timber panels called zar (meaning membrane) and cupboards. Doors, opening to the adjacent (tokana or harem) rooms, cupboard doors, various open or semi-open shelves and tiny alcoves called gilve were all included within this surface creating strong centers, as defined by Christopher Alexander (2002). They have their own local symmetries and are well integrated in size, scale, style carvings and finishing or paints (Figure 4-6; see also Figure 23a, 36a, b, e, in İmamoğlu, 2006). As can be seen in these figures, there was always a unifying design theme and colour scheme on these surfaces.

Wall panels were generally made in similar designs, interrupted by shelves or doors, and sometimes, they were alternating repetitions of figures and moldings. In this occasion, one may recall some of the room decorations realized in various parts of the Ottoman Empire beginning from 15th century. The earliest examples of these are probably seen in hamam odasi of Güpgüpogulları Konak in Kayseri or Murat II Room in Muradiye, Bursa, in which wall panels were decorated with flower paintings, cypress trees and floral bouquets (İmamoğlu, 2002; Tomsu, 1950). Eldem (1984) illustrates similar wall panel designs from Kütahya, Gebze, Bursa, İstanbul and Tekirdağ, all from the 17 th or 18 th centuries. A well-known example is the yemiş odası in Topkapı Palace which was created in 1705 during "Tulip Period" in İstanbul. Sultan Ahmed III had this room to be designed in his private section. In this room still life painting of floral bouquets arranged in vases and baskets of fruit covered the paneled wall surfaces. Another example may be given from Aleppo. It is the reception hall of a house of a Christian family built in early 17th century, now exhibited in the Museum of Islamic Art in Berlin: wall panels of the room were covered with high- 


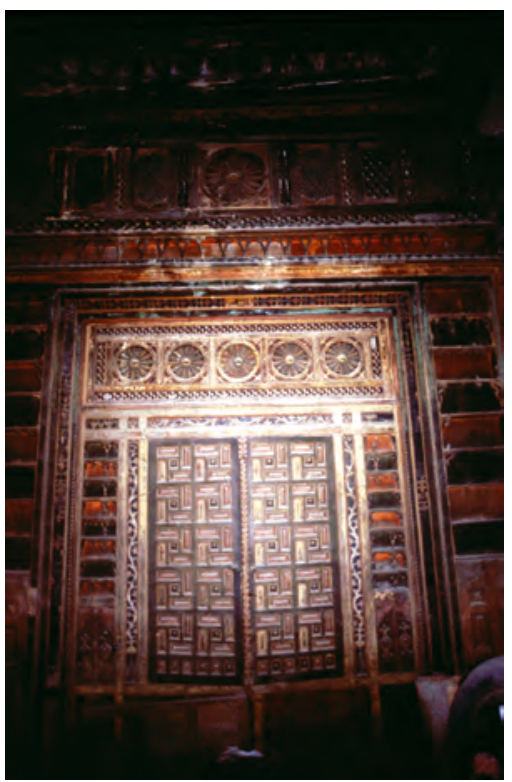

Figure 7. South wall of Gavremoğlu's sofa.

Figure 8. South wall of Güpgüpoğulları's sofa.

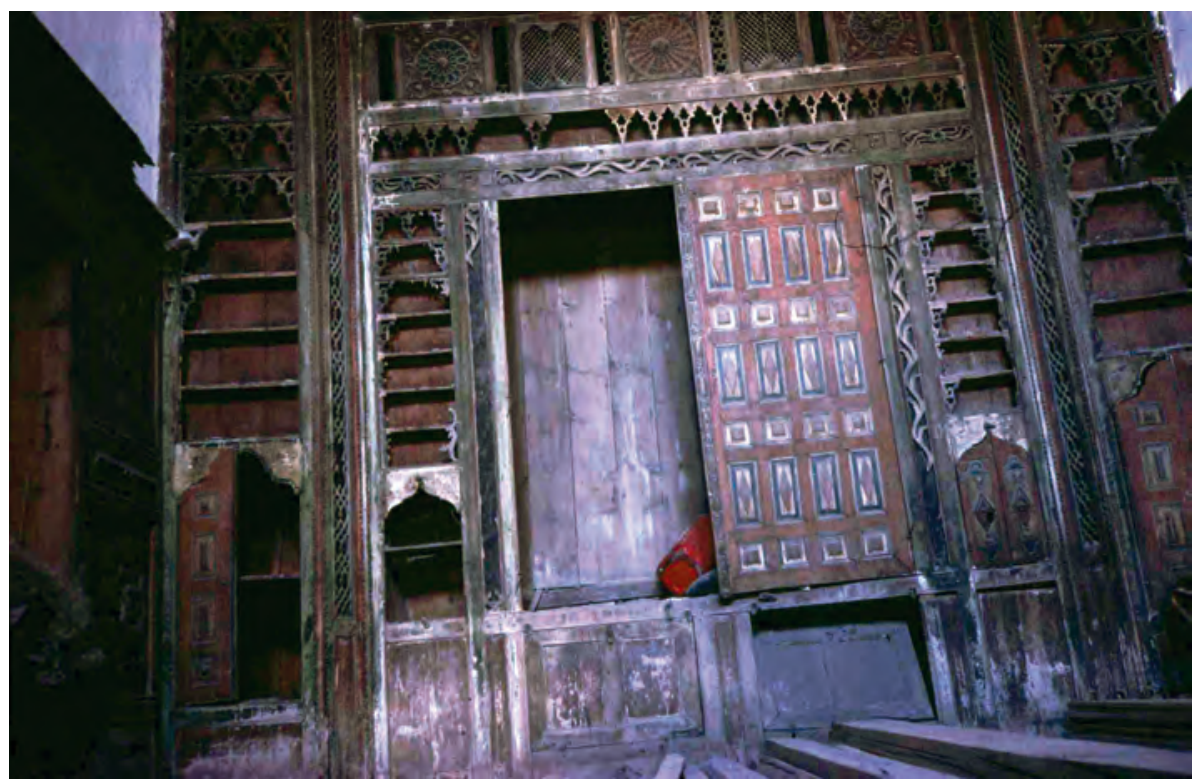

quality floral painting enriched by the addition of birds and fabulous creatures (Gladiss, 2000). Walls in all these examples carry many common features of a zar of a Kayseri sofa: a careful design approach to wall panels; utmost care for proportions of panels, doors and alcoves; molding or painting the wood surfaces with abstract or realistic floral figures; integrating lower part of the panels with the upper cornice or continuous top shelf; and utilizing bold colour schemas of reds, yellows, greens in a harmonious blend.

The section above the paneled part is a wide plastered surface, which is either left as it is, or decorated with frescoes. Although we do not have clear or sound examples of such painted surfaces today, we have the remnants of them in Gavremoğlu (1774) and Zennecioğulları (1593) sofas. In the former one, one could detect the lines or forms of a Pompei type painting, with classical columns scattered in a sloping green landscape. In the latter case the leftover frescoes were similar to those present in some of the rooms in mabeyn and ikballer flats of Topkapı Palace, built during Abdülhamit I period, in which floral figures were utilized to cover large surfaces (İmamoğlu, 2002; Eldem and Akozan, 1982, L.212, 222-3).

3. The wall opposite to the entrance -and in almost all cases, the one oriented to south-is the most impressive of all the walls of the room. It is like the focal surface within the space and all other surfaces or connecting shelves somehow direct the attention of onlookers towards this plane. The whole surface, from bottom up to the ceiling is carefully designed and meticulously constructed and painted (Figure 7, 8). A clear axial, local symmetry is apparent in the design and all elements are housed within this principle. Although in classical examples, this wall was completely covered with timber membranes and paint, other solutions were also produced in the 19th century. For example in Öztaşçı sofa (1877), the upper section of this wall was decorated only by scenery paintings on three apses: the central one was dominant in size and had a small inward projection; the flanking ones were illusionary -created by simple perspective tricks. All three, framed with repetitive, simple decorative elements, depicting 
Figure 9. Northeast wall of Öztaşç1's sofa, construction date: 1877 .

Figure 10. Upper part of the south wall of Güpgüpoğulları Konak after its restoration. (İmamoğlu, 1995, 103).
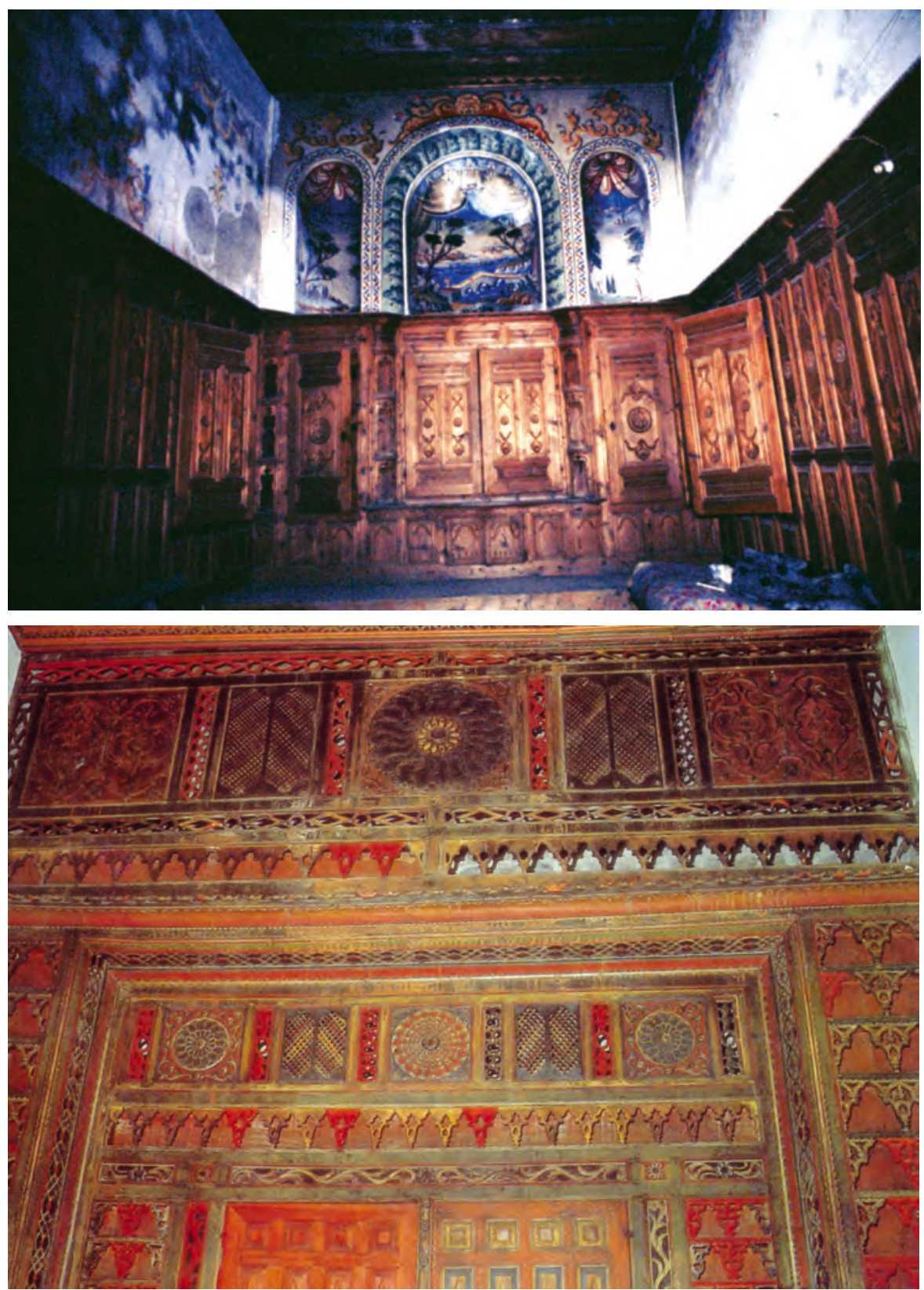

landscapes with buildings on a seaside with decorative pine and cypress trees scattered around (Figure 9; also see İmamoğlu, 2006, Figure 75a).

In a typical traditional house, as mentioned above, all design elements of the south wall is produced with timber; a timber frame runs around the whole surface and between an upper and a lower zone. The zar on the upper zone is made of various panels or screens in squares or rectangles, creating a band. It encloses a small cabin called çardak (meaning mezzanine) behind its surface. One can climb up to çardak with a portable ladder and hang hevenk grapes, store pears or other fruits with pleasant scents. This portion of zar generally includes an odd number of decorative figures to create a strong axial symmetry. In the central position there is generally an abstract rose or daisy figure or a "çark-1 felek" (wheel of god/ fortune), on its sides there are trees or cypress trees created by timber grills 


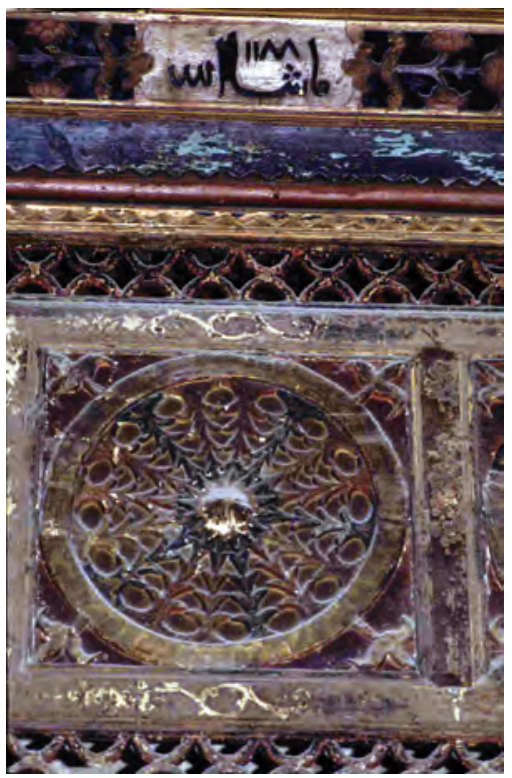

Figure 11. Central medallion on the south wall of the Gavremoğlu's sofa.

Figure 12. A detail from the south wall of Gavremoğlu's sofa.

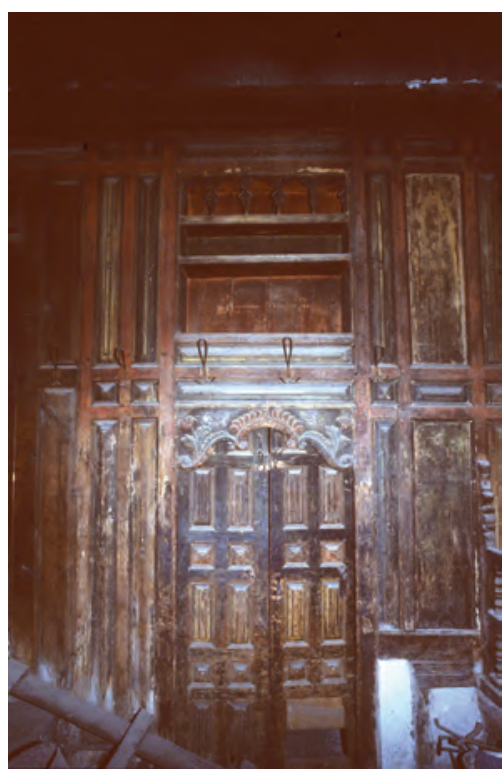

Figure 13. A detail from the east wall of Gavremoğlu's sofa.

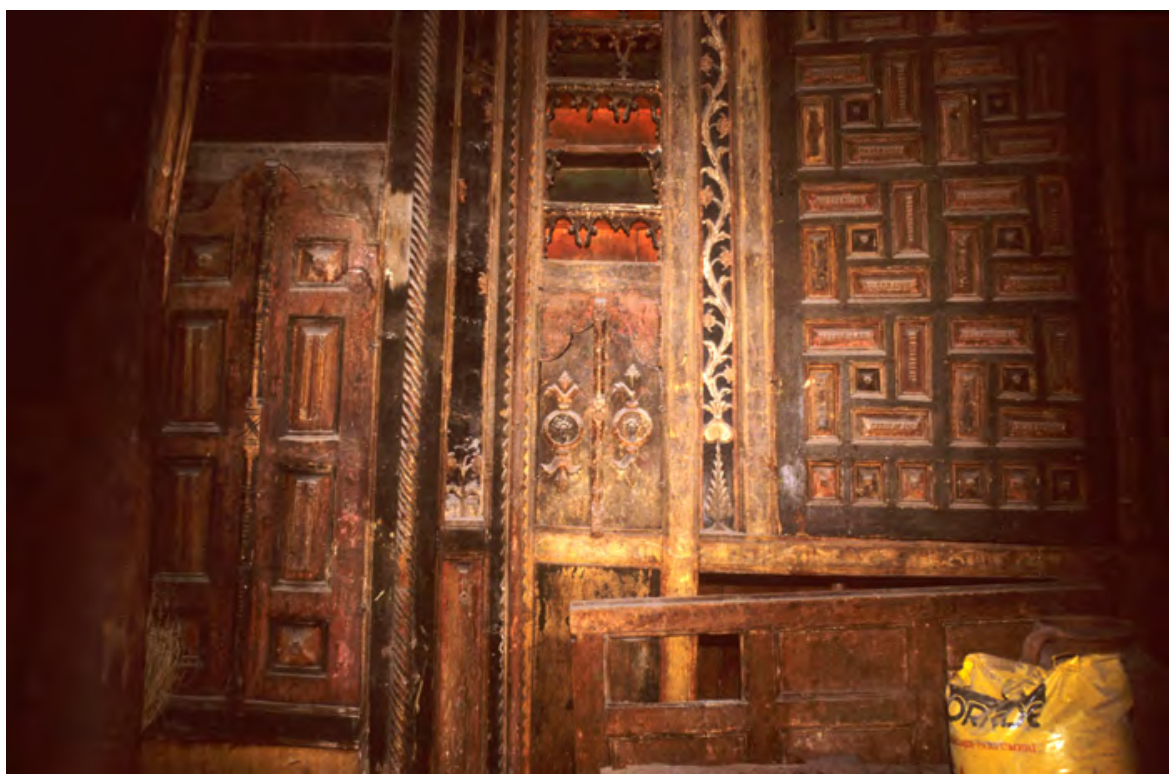

or molded panels composed in a symmetrical fashion. These larger squares or rectangles are connected with each other by decorative floral timber elements (Figure 10). Use of timber grills lets the air circulate between the room and çardak area, and hence, enhances sofa to be filled with the smell of the stored fruits. This smell, as well as the smell of pine wood logs carrying the roof, and surface finishings helps to create a multi-sensory environment.

The above-mentioned lower zone of this wall is allocated for storage purposes. It is generally in the shape of a square, divided into small rectangular units by cornices or decorative frames. Usually there is one large central rectangle (we may name it as "yüklük, gilve and medallions" section) and at least two vertical side rectangles (far side cupboards and gilves). At the lower part of this central rectangle there is always a large cupboard called yüklük covered by two decorative doors. A cornice surrounds these doors and separates them from the adjacent units. (In case of Baldöktü house which is a 19th century house with a relatively small sofa, şerbetlik replaced the yüklük.) On two sides of the yüklük doors, there are smaller cupboards at the bottom and small alcoves above (Figure 7-9). These alcoves run up to the top level of the yiuklük where one comes across a horizontal rectangle zone (we may call it a medallion or lower grilled section), again made of grilled elements. This rectangle surface, which is the crown of the cupboard doors, and vertical row of decorative alcoves, is composed of three or five major medallion figures with some auxiliary decorative elements in between.

The "far side cupboards and gilves" toward the corners are also made of small cupboards on the lower level, and small alcoves above, going up to the bottom of the çardak level (Figure 2,7). The very top of this square part is separated from the çardak zone by a large band of a horizontal cornice composed of two or three lines of decorative figures or a series of tiny horizontal pigeon holes.

In some sofas, central upper parts of the medallions section, may contain certain inscriptions, prayers or other decorative elements. For example, in Gavremoğlu's sofa, the date of construction of the building is indicated 
as 1188 (1774 AD) and with an inscription of "maşallah" meaning "may god preserve", on the upper part of the central medallion (Figure 11). According to the owner of the house, there used to be also a golden horn placed above the inscription of maşallah.

In general, proportions and articulations of wall panels, their colour schemes and delicacy of workmanship indicate the sensitive, subtle and coherent design concept prevalent in almost all sofas (Figure 5, 12, 13). Moldings on wood panels and cornices, as well as top shelves stick out from the surfaces, while decorative gilves and embedded shelves stay in the dark. If wall panels were not molded, but kept plain, they would be painted with floral figures (İmamoğlu, 2006, Figure 36e). All panels, plain or carved, are generally painted in greens, browns, beiges or scarlet and lace-like timber surfaces under the north light create a sober, but sophisticated, pleasant and peaceful atmosphere.

\section{CEILINGS OF SOFAS}

In traditional houses one can see two different approaches towards the design of ceilings: in earlier examples, designs were kept simple. But especially after the first half of the 19th century, like the ceilings of other rooms of the houses, ceilings of sofas were decorated with wood inlay to create geometric patterns that usually enhanced the centring quality of rooms and painted in colours similar to or harmonizing with the walls.

Though relatively simple in nature, ceilings of sofas were carefully treated. In classical type of houses, the load carrying timber logs were exposed. Evenly spaced logs and the surface above them were painted in the general colour scheme of the room. A narrow timber cornice on the connection lines ran around the ceiling and painted in the same colours. This approach created a kind of functional beauty and a kind of balance between the elaborate decoration of walls and the simplicity of ceiling. Quite a number of old sofas, including Gavremoğlu's were designed in this fashion, in which the ceiling was composed of evenly spaced logs supporting the wood sheathing, which had equilateral quadrangles created by timber laths. The colour scheme of the sheathing and figures complement those of the logs, which were painted in such a way that two browns and one black followed each other (İmamoğlu, 2006, Figure 66). A similar colour scheme is seen in Güpgüpoğulları's sofa as well (Çakıroğlu, 1952).

Sofas built or renewed in late 19th and early 20th centuries were treated like other rooms of the houses and their ceilings were elaborately decorated. A timber panel either having a central design figure (two or three dimensional) or a flat surface-pattern covered the load bearing logs, and was painted in harmony with the wall panels. In Bezircioğlu House, low profile, curved timber laths cover the greater portion of the ceiling, framed with a peripheral zone. The corners of the frame were filled with angel figures playing horns.

\section{DISCUSSION}

The sofa in a traditional Kayseri house is an elegant, sophisticated space. Though it has a very small fenestration area, hence have a dim, even dark atmosphere, its proportions, general arrangements and treatment of its surfaces create an extraordinary aura. A deep-rooted tradition determined 
its design principles and left little room to divert its overall character in time.

Although almost every Muslim house had a sofa, their sizes and decorations must have varied according to the socio-economic status of the family. However, whatever group was involved, their builders tried to keep up with the existing standards of their time. Probably the most elaborate sofas were built for konaks or residences of well-to-do families of the town. Administrators or rulers (like Güpgüpoğulları, Zennecioğulları) or prosperous traders or land owners (like Gavremoğlu, Mollaoğulları, Cıngıllıoğlu, Camızlar, Bağdatlılar, etc.) had the classical type of elaborate sofas in their houses. The earliest example of this sort is probably Güpgüpoğulları's, which was built in 15th or 16th century. This tradition ended in the 20th century with the establishment of the Turkish Republic.

The overall design of a sofa expresses a clear wholeness. It is simple and provides inner calm and serenity, though it is rich with various design elements. In line with the ideas of Alexander (2002, Book I, 179), it is a living structure, and its design has a beautiful, limped, and almost deceptive simplicity. Each sofa includes a well-integrated lower portion including cupboard units, small alcoves, wall paneling surrounding the space; and a large surface (or void in Alexander's term) on the upper part, embellished with frescoes. Then, each of these sections has many strong centers of their own at various levels of scale.

Precise and efficient use of timber, in its inherent beauty, is the underlying aesthetic features of wall panels. Like the use of stone on exteriors, timber was sensitively treated on interior surfaces and worked in bold or delicate patterns, varnished or painted carefully. Regardless of the socio-economic status level of the owners, these were the essential elements in every sofa. Since they were considered important, it is expected that in a long history of building, imaginative and elegant examples were created, some of which are worth preserving as artifacts.

Sometimes, instead of moldings, paintings of various kinds decorated timber wall panels. In some examples the amount of decoration was considered excessive and somehow questioned (or criticized) with a tacit kind of admiration. For example Gavremoğlu's sofa was named as "namaz kllinmaz sofa" (meaning, sofa where one cannot pray, perhaps due to the distracting nature of décor for the praying person); floral painted wall panels, scenery frescoes above zar level, spectacular design of its south wall and impressive colour scheme of the room, all together glittered like gold in the modest, ordinary everyday life of people in a dusty medieval town.

Christopher Alexander (2002, Book IV, 27) states that
"the goal of architecture is to intensify the degree of life in space. Function cannot then be a practical matter separate from beauty. All functional forms will also be ornamental, as they are in nature. The artist, working from this spirit, will naturally and spontaneously bring colour, detail, and ornament into his work, because it is necessary to bring that space to greater life."

In this sense, sofas in Kayseri houses are full of life.

In the above sense, the most remarkable part of sofas is the wall oriented to kible direction. Its entire surface was carefully designed and well integrated with other parts of the room. Various visual centers on side walls, including moldings or paintings as well as cornices and shelves; adding to the arrangements of carpets on the floor and light coming from 
the opposite direction, directs one's attention towards this wall. It is like the climax or strong center of all decorations and catches the eyes of people entering the space. A delicate and lavish design on this wall goes up to the ceiling and gives an altar or mihrap-like impression. Sofa with its south wall and other qualities may be interpreted as playing the role of a family shrine or a small namazgah (praying space/environment). This is somewhat supported by its accustomed role in Ramadan periods, when it was often used for late-night prayers (teravih namazi) by male family members and a large group of neighbors. During this activity, like other prayer times, worshippers directed their supplications toward it, looked or gazed at it as well as the carpets or prayer rugs over which they were praying, and probably admired the enduring splendors of art and handcraft, which was perhaps an abstract, modest representation of beauties of eternity -in one sense, a blurred reflection of the ultimate creator- Allah on earth. Thus, instead of figurative representations of other religions, it is the abstract representation of Islam, like a hermetic artifice (a sealed ingenuity) through which the principles of art -secret science- is written with timber and paint.

Colour scheme of sofas was an important component of their designs. Combinations of browns, reds, greens; blues, beiges, scarlet or gold, all in subtle tone, enlivened the room surfaces. It is basically the paintwork applied on timber panels (and sometimes above the panel walls and ceilings) that harmonize with the colour schemes and unify all design elements within the space. Utilization of colour is quite effective and powerful, achieving a pleasant, if not spectacular atmosphere. In this sense one can say that traditional painters worked with passion and creativity using their wit, wisdom, artistic talent and skills.

The complexity, delicacy and colourfulness of design elements in various gradations on surfaces were also remarkable. They were generally used in different rhythms and integrated with solemnity and care. A mature unity and balance or a strong "wholeness" was achieved not only by use of colour, but also by dimensioning and detailing. In that sense one can talk about "unity in diversity, multiplicity in one" in these surfaces (2). The end result was an impressive interior, a kind of sacred space for families and other users. Visitors seeing such sofas often exclaimed, "Could there be such a master builder on earth?" (İmamoğlu, 2006, 283, Note 41). In one sense, Kayseri sofas somewhat reflect the glory of Ottoman period and the enduring splendor of a timeless interior with peaceful, elegant yet unpretentious atmospheres. They are not only functional for formal and ceremonial activities in the house, but also suitable places for contemplation and inner calm, in which people can find tranquility and serenity. These spaces are perhaps, few examples of a rich spectrum of Anatolian cultural heritage and indicate the homage of a long tradition of Ottoman artists toward interior spaces.

Kayseri sofas with their above mentioned characteristics differ from sofas seen in western Anatolia and Balkans, and may share some characteristics with some of the rooms designed in eastern parts of Anatolia and Middle

2. Cooper English in her dissertation emphasizes the importance of similar concept in Russian Architecture and gives statements of a number of authors on "the invisible dimension of the visible", the "divine energy that penetrates into the visible so that we can see it" (p. 240), and synonymousness of architecture with mysteriousness (p. 14).
Eastern cities. While types seen in the western Anatolia and Balkans were categorized by many scholars and regarded or shared as common knowledge, this is not the case for Kayseri sofas which displayed a symbolically important space. It was a room, a solid enclosure and a distribution space, but its "roominess" was such that it superseded all other rooms in the house in size and levels of decoration, gaining an extraordinary, unforgettable identity. It acted as a family shrine, or an 
abstract sort of small temple. It became almost an icon representing spiritual energies of architecture.

Sofas in Kayseri have definitely glowed and glittered for ages in houses and perhaps affected individuals in a positive manner; providing peace, joy and happiness, helping them to understand and appreciate aesthetic values, creative talent, intuitive and spiritual dimensions in their everyday lives. These houses unfortunately disappeared in a relatively short period of time due to the destruction of historical neighborhoods of the town since 1950s. However, sofa in a traditional Kayseri house may be considered as one of the significant tributes to the architecture of Ottoman Anatolia and very few residential spaces exist that equals the architectural quality of it in a large geographical domain. These sofas carry certain architectural mystery and invisible dimension of the visible. Hence there are lots of things to learn from them for architects and interior designers and the subject deserves further research.

\section{REFERENCES}

ALEXANDER, C. (2002) The Nature of Order, An Essay on the Art of Building and the Nature of the Universe: Book one: The Phenomenon of Life, 476 pp. Book two: The Process of Creating Life, 635 pp. Book three: A vision of living world, $697 \mathrm{pp}$. Book four: The luminous ground, $356 \mathrm{pp}$. The Center for Environmental Structure, Berkeley, California.

AHMED NAZİF (1987) Kayseri Tarihi, M. Palamutoğlu prepared the manuscript from the original Ottoman text, Kayseri İl Özel İdare Müdürlüğü ve Belediye Yayınları, Kayseri.

AINSWORTH, W.F. (1842) Travels and Researches in Asia Minor, Mesopotamia, Chaldea and Armenia, v.2. John W. Parker, London.

COOPER ENGLISH, E. (2000) The Origin of Soviet Avant-Garde Rationalist Architecture in the Russian Mystical-Philosophical and Mathematical Intellectual Tradition, Unpublished PhD thesis, University of Pennsylvania.

ÇAKIROĞLU, N. (1952) Kayseri Evleri, İTÜ Mimarlık Fakültesi Yayınları, İstanbul.

ELDEM, S.H. (1984) Türk Evi -Osmanlı Dönemi I, TAÇ Vakfı, İstanbul.

ELDEM, S.H. and AKOZAN, F. (1982) Topkapı Sarayı, Kültür ve Turizm Bakanlığı, Eski Eserler Genel Müdürlüğü, İstanbul; L 222-3.

Evliya Çelebi Seyahatnamesi (1970) Beşinci Kitap, Türkçeleştiren Zuhuri Danışman, Zuhuri Danışman Yayınevi, İstanbul; 60-79.

GLADISS, A. von (2000) Architecture (Ottoman Empire), in Islamic Art and Architecture, M. Hattstein and P. Delius, eds., Könemann, Cologne, $565 \mathrm{pp}$.

İMAMOĞLU, V. (1980) Microclimatic elements of houses in Turkish arid zones, in Gideon Golany, ed., Housing in Arid Lands: Design and Planning, The Architectural Press, London; 45-74.

İMAMOĞLU, V. (1988) Children's home environments in three socioeconomic-status groups in Ankara, METU Journal of the Faculty of Architecture, v: 8, n: 1; 45- 57. 
İMAMOĞLU, V., İMAMOĞLU, E.O. (1990) Housing and living environments of urban families in Ankara, Open House International, v: 15, n: 2, and 3; 9-13.

İMAMOĞLU, V. (1995) Kayseri, Kayseri Valiliği Kültür, Sanat ve Turizm Vakfı Yayınları No: 4, Kayseri.

İMAMOĞLU, V. (2002) Kayseri Evlerinde Duvar ve Tavan Resimleri, in M. Denktaş, Y. Özbek and A. Sağıroğlu Arslan, eds., VI. Ortaçă̆ ve Türk Dönemi Kazı Sonuçları ve Sanat Tarihi Sempozyumu, Bildiriler, Kayseri Erciyes Üniversitesi, Kayseri; 417-27.

İMAMOĞLU, V. (2006) Traditional Dwellings in Kayseri, extended second edition, Kayseri Büyükşehir Belediyesi Kültür Yayınları No: 49, Kayseri, 290 pp.

İMAMOĞLU, V. (2010) Gesi Evleri: Mimar Sinan'ın Yetiştiği Yöredeki Köyler ve Geleneksel Evler, Kayseri Büyükşehir Belediyesi Yayını, 439 pp.

TOMSU, L. (1950) Bursa Evleri, İTÜ, Mimarlık Fakültesi, İstanbul.

Alındı: 03.03.2010

Anahtar Sözcükler: Sofa; Osmanlı iç mekanları; geleneksel dekorasyon; Kayseri evleri; mihrap duvarlar.

\section{GELENEKSEL KAYSERİ EVLERİNDE BİR ZERAFET İFADESİ OLARAK SOFA}

Anadolu'nun ortasında, tarihi yolların kesişme noktasında bulunan Kayseri'nin zengin bir mimari geçmişi vardır. Kentin Roma, Bizans, Selçuklu ve Osmanlı uygarlıklarından izler taşıyan taş evleri, onları oluşturan ahşap kaplı odaları, özellikle de sofaları Anadolu mimarlığının ilginç örnekleri arasındadır. İkinci Dünya Savaşı sonrasında modenleşme uğruna hızlı bir yıkıma uğrayan kent, zengin tarihi evlerini ve hemen hemen tüm eski mahallerini kaybetmiş olsa da, ayakta kalan birkaç ev ile belgelenmiş olan bazıları, Osmanlı dönemindeki mimarlık ve dekorasyon sanatımıza ışık tutacak nitelikler taşır.

Eski Kayseri evleri genellikle yoğun bir kent dokusu içinde, bir avlu veya küçük bir bahçe etrafında oluşmuş, asimetrik düzende, içe dönük yapılardır. Damları düzdür. Odaları, özellikle de sofaları, keskin prizmalar şeklinde dışarı yansıtılmıştır. Çok yalın dış görünüşlerine karşın evlerin iç mekanları renkli ve etkileyicidir. Kayseri evlerindeki sofalar evlerin en önemli mekanlarıdır: Sekialtı adı verilen giriş bölümü sofanın iki yanında bulunan harem odası ve tokanaya geçit verirken, ana mekan günümüzdeki salon veya konuk odası görevini yüklenmiştir. Sofalar ayrıca namaz kılınan bir mescit, aynı zamanda evdeki yaşlıların yatak odasıdır. Büyük boyutlara ve yüksek bir tavana sahip olan sofa, evin en özenilerek tasarlanan mekanı, ailenin dışa gösterilmek istenen yüzüdür. Giriş kapısı, kapı üstündeki veya yanlarındaki pencereleri avluya açılır, diğer duvarları sağır bırakılmıştır. Yan duvarları ve kapı karşısına gelen duvarı zar adı verilen dekoratif ahşap panolarla kaplanmıştır.

Sofası olan evlerde yapılan incelemeler sofa girişlerinin büyük çoğunlukla kuzeyde yer aldığını ve girişin karşısına gelen duvarın kıble yönünde olduğunu göstermiştir. Sofa evin, kıble duvarı da sofanın en özenilerek tasarlanan ve dekore edilen bölümüdür. Bu duvar yerden tavana kadar uzanan bir bütün olarak ele alınmış, simetrik bir düzen içinde yüklükler, 
dolaplar, gilveler ve çeşitli madalyon ve dekoratif elemanlarla süslenmiş, uyumlu renklere boyanmıștır. Kıble duvarı, bu özellikleriyle de, adeta önünde diz çöküp dua edilecek, bir mihrap-duvar haline dönüştürülmüştür.

Sofaların uzun olan yan duvarları 250-270 cm yüksekliğe kadar o yüzeydeki kapı, dolap kapağı, gilve ve terekleri içine alan zarlarla kaplanmış, zarların üzerinden tavana kadar olan bölümü ise ya sıvanıp boyanmış, ya da duvar resimleriyle süslenmiştir. Sofa tavanları bazen sadedir; damın yükünü taşıyan direkler olduğu gibi aşağıdan görünür; bazen de ahşapla kaplanmıştır. Ahşap kaplı tavanlar göbekli veya göbeksiz olabilir. Her durumda tavanlar duvardaki zarlarla uyumlu olacak şekilde boyanmiştır.

Kayseri sofaları geleneksel Osmanlı mimarlığının dikkate değer mekanlarıdır. Bu sofaları yapan mimar veya ustaların, ahşap ve renk kullanmadaki ustalığı, kompozisyonlarda sergiledikleri hayalgücü ve beceri olağandışıdır. Onların mekan oluşturmada sahip oldukları bilgelik, birikim ve duyarlılık, tasarladıkları sofalarla ortaya koydukları bütünlük ve etkileyici atmosfer, evrensel güzellikler sergiler. Bu güzellik, mimarlık sanatının söze dökülemeyen, psikolojik ve ilahi boyutlarını bize gösterir. Kayseri sofalarının sahip olduğu nitelikler, geniş bir coğrafya içinde bile çok az iç mekanda görülecek düzeydedir. Bu özellikleriyle de, bu sofalar mimarlık tarihimizin başarılı örnekleri arasındadır ve günümüz mimarlarına yol gösterici nitelikler taşır.

VACİT İMAMOĞLU, B.Arch., M.Arch., M.Sc., Ph.D.

Received his B.Arch and M.Arch from METU, his M.Sc. from Pratt Institute, and his Ph.D. in architectural psychology from University of Strathclyde. Is a Professor at METU, currently teaching architectural design, research methods and universal design courses. imamoglu@ $\underline{\text { metu.edu.tr }}$ 